\title{
ADMINISTRATIVE DUE PROCESS HEARING REQUIREMENTS AND THE FEDERAL MARITIME COMMISSION
}

GEORGE H. HeARN*

The United States Court of Appeals for the District of Columbia Circuit has contributed much to the field of administrative law. In a very recent case, Marine Space Enclosures, Inc. v. FMC, ${ }^{1}$ that court dealt with the constitutional principle of due process as it applies to the holding of hearings before administrative agencies. Specifically, the court considered the question of when a hearing must be held in certain cases before the Federal Maritime Commission and what type of hearing suffices in law. The importance of these issues generally, and particularly to the Federal Maritime Commission, indicates that an analysis of the issues considered by the court is needed at this time.

I

In Marine Space Enclosures the District of Columbia Circuit Court of Appeals held that the Federal Maritime Commission acted contrary to law when it failed to hold a hearing before approving two agreements presented to it for approval. ${ }^{2}$ The agreements provided for the construction and maintenance of consolidated marine passenger terminal facilities in the port of New York City and for the use of the facilities by passenger vessel operators. ${ }^{3}$ Under the Shipping Act of $1916{ }^{4}$ approval of such agreements by the Federal Maritime Commission is required before they may be

* Member, Federal Maritime Commission. B.A. 1950, St. Francis College (Brooklyn); LL.B. 1954, St. John's University; Member, New York State Bar; Lecturer, American University School of Law; Federal Maritime Commission Representative in the Administrative Conference. The writer wishes to express his appreciation for the assistance of Eliot J. Halperin, his Special Assistant, Member, New York State Bar.

1. 420 F.2d 577 (D.C. Cir. 1969).

2. Id.

3. FMC Agreements Nos. T-2271 \& T-2272, FMC Docket No. 69-47 (T-2271 dated Jan. 17, 1969; T-2272 dated Jan. 15, 1969; both filed Feb. 20, 1969). The first agreement is a passenger terminal lease between the City of New York and the Port of New York Authority and an agreement to construct new marine passenger facilities in the City. The second agreement is between the City of New York, the Port of New York Authority, and passenger vessel operators and provides for use of the new facilities and certain interim facilities pending completion of the new terminal.

4. 46 U.S.C. $\S \S 801-42(1964)$. 
implemented, ${ }^{5}$ and these had been filed for approval in February 1969. The agreements were then noticed in the Federal Register, ${ }^{6}$ and at the request of the Port Authority and the Mayor of New York City the usual twenty-day notice period was shortened to twelve days. ${ }^{7}$ A protest against approval of the agreements was received from Marine Space Enclosures, Inc., and was concurred in by its affiliate, the American Dock Company of Staten Island, New York. Other comments were received urging immediate approval of the agreements as being in the public interest. ${ }^{8}$

The protests, and subsequently the court proceeding, focused on several restrictive covenants contained in the agreements. It is provided in the first agreement that the City and the Port Authority will not

promote, finance, establish, construct, operate, or maintain any pier, wharf, bulkhead, dock, terminal or other facilities for the accommodation of passenger vessels, or authorize any other person so to do [for a term] no more than fifty years after the expiration of the original term of the letting of the permanent premises.'

The original term is 23 years -3 years for the interim terminal and 20 years for amortization of a bond issue for financing the project. Thus the total term after completion of the new terminal would be 70 years. ${ }^{10}$

A related restriction provides that "neither the City nor the Port Authority will issue any work permit or other construction approval or consent whereby structures suitable for [passenger terminal] operations may be provided . . . anywhere within the jurisdiction of the City or Port Authority."11

The chief protestant, Marine Space Enclosures, Inc., stated that

5. Id. $\S 814$.

6. 34 Fed. Reg. 3639 (1969).

7. The twenty-day period is not provided for by rule or statute, but has been traditionally granted by the Commission. But see 46 C.F.R. § 529.21 (1969).

8. New York Chamber of Commerce; New York City Council on Port Development and Promotion; Cunard Steam-Ship Company, Ltd.; French Line; International Longshoremen's Ass'n, AFL-ClO.

9. 420 F.2d at 580-81.

10. Id. at 581 .

11. Id. at $581 \mathrm{n} .3$. By a combination of provisions in the two agreements, it is further provided that vessel operators serving the Port of New York shall not operate at any terminal facility other than the one to be constructed. Under the second agreement all passenger vessel operators may become signatories to the agreements, and no such operator may use the new terminal without becoming a signatory. These restrictions are coextensive with the 70 year term of the first agreement. 
it is interested in constructing and operating a terminal facility different than the one proposed in the agreements and that because of the anticompetitive covenants in the agreements, the protestant would be barred from establishing its terminal. ${ }^{12}$ Protestant argued that the anticompetitive provisions were prima facie contrary to the public interest standard of applicable law and that the agreements should be disapproved or subjected to an "evidentiary" hearing.

The City and the Port Authority responded to the protests, stating that the agreements had been the subject of public hearings before the New York City Council and had been approved by the Board of Estimate of the City of New York without opposition. ${ }^{13}$ The Marine Space terminal proposal had been presented in the hearings and rejected. It was further contended that a hearing before the Federal Maritime Commission would cause financially harmful delay and that the restrictive provisions did not preclude operation of terminal facilities in the Port of New York other than the proposed terminal. ${ }^{4}$ In addition the response noted that no vessel operators had formally intervened or protested before the Commission. ${ }^{15}$ The City and Port Authority represented to the Commission that the new facilities would have to be finaneed by public funds, and that a $\$ 60,000,000$ bond issue was contemplated; and during preliminary discussions the Commission was told that such funds could not be obtained without the long term exclusive commitments contained in the agreements. ${ }^{16}$

The Commission received further submissions from the proponents and protestants of the agreements. They related to alleged coercion by the Port Authority to get several carriers to sign the agreements. The protestants contended that although no protests had been received, the carriers harbored reservations as to the agreements. Although the agreements contain spaees for eighteen carriers' signatures, only six had signed as of the date of the court of appeals decision..$^{17}$

On April 7, 1969, the Commission issued its Order of Approval. The Commission found that "Proponents have demonstrated a

\footnotetext{
12. Id. at 581 .

13. Id. at 582 .

14. Id.

15. $I d$.

16. See also Supplementary Response of the Port of New York Authority, Agreements Nos. T-2271 \& T-2272, at $11 \& 13$ (Mar. 21, 1969).
}

17. 420 F.2d at 582. 
transportation need for the agreements and it would appear that the agreements are not unjustly discriminatory or unfair or detrimental to the commerce of the United States and are not contrary to the public interest." 18 Further, the Commission concluded that "the transportation need is so clear we consider it essential that the project be permitted to be initiated as soon as possible."10 The protests were rejected by the Commission on the grounds that "the proposals of protestant were rejected by officials of the City of New York"20 and the protestants' interests appear "indirect and remote."21

As to the anticompetitive provisions of the agreements, the Commission acknowledged their restrictive nature:

Under Section 15 of the Shipping Act, 1916, the Commission retains full power of surveillance over approved agrcements as a condition of approval. The Commission, after approval, retains the power to "cancel or modify any agreement, or any modification ... thereof, whether or not previously approved by it, that it finds to be unjustly discriminatory or unfair . . . or to operate to the detriment of the commerce of the United States, or to be contrary to the public interest, or to be in violation of [the Shipping Act, 1916]. . . .'"22

Subsequent to the Commission's approval, seven carriers requested the Commission to meet with them for informal discussions concerning the agreements. Later, a group of seven carriers moved for and was granted leave to intervene in the court of appeals. ${ }^{23}$

On May 12,1969, the Commission issued its Supplement to Order of Approval, which discussed a "Stipulation of Proponents" submitted to the Commission on May 8, a month after the original order of approval. ${ }^{24}$ By that document the City and Port Authority, "at the suggestion of the Department of Justice [agreed] to resubmit the agreements for Commission review at least six months prior to the termination of the original lease term of 23 years." ${ }^{25}$ The Commission affirmed its prior approval and added that

[i]n view of this, stipulation the Commission will at that point [at the end of

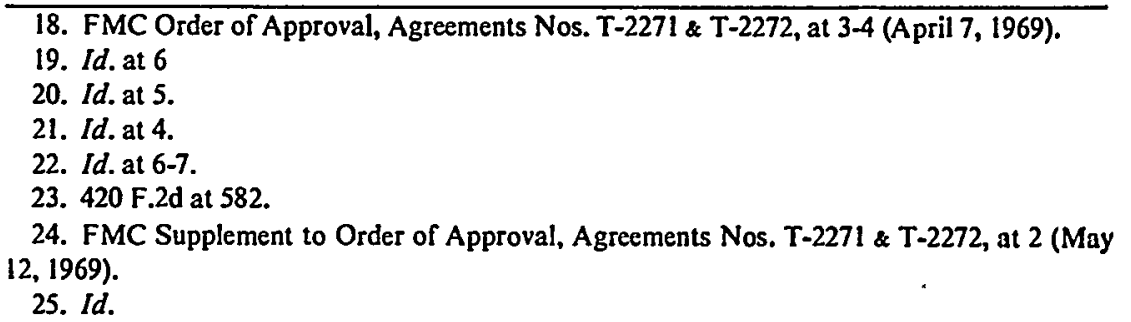


23 years] review the agreements in light of current circumstances and decide anew whether any continued anticompetitive agreements would be in the public interest. This, we believe, will insure the protection of the public interest.....2

Further, the supplemental order noted the request of seven carriers for informal discussions with the Commission, but stated that the carriers had not desired to submit a formal protest. ${ }^{27}$

11

The immediate effect of the circuit court's decision to remand the case to the Commission for a hearing is not the most significant aspect of the case. Of course, implementation of the agreements has been delayed, and the proponents have since requested the Commission to hold a public hearing on the agreements..$^{28}$ In fact, it is difficult to find fault with the result reached by the court. ${ }^{29}$ What is debatable, however, is how the court reached its conclusion. That is the significant aspect of the case. The court said that not only is a hearing prior to approval of the agreements required in this case, but a hearing is statutorily mandated before any agreement may be approved..$^{30}$

To appreciate the significance of this statement it is necessary first to understand the statutory scheme involved. Section 15 of the Shipping Act, 1916 provides, inter alia:

The Commission shall by order, after notice and hearing, disapprove, cancel or modify any agreement, or any modification or cancellation thereof, whether or not previously approved by it, that it finds to be unjustly discriminatory or unfair as between carriers, shippers, exporters, importers, or ports, or between exporters from the United States and their foreign competitiors, or to operate to the detriment of the Commerce of the United States, or to be contrary to the public interest, or to be in violation of this Act, and shall approve all other agreements, modifications, or cancellations."

26. Id. at 4 .

27. Id. at 1 .

28. Such a hearing was instituted by Commission order of September 12, 1969. 34 Fed. Reg. 14485, 14486 (1969).

29. During Commission deliberation on the two agreements, certain reservations were expressed as to their restrictive provisions. I expressed my concern by motions for hearings on the agreements which failed to carry. Federal Maritime Commission, Minutes of Commission Meetings, April 4, 1969. Ultimately, however, the Commission concluded that its fears would be arrested by the terms of its Order of Approval. Id., April 4\& 7, 1969.

Subsequently, I voted against Commission issuance of the Supplement to Order of Approval because I considered a hearing on the agreements necessary. Id., May 12, 1969.

30. See note 2 supra and accompanying text.

3I. 46 U.S.C. § 814 (1964) (emphasis added). 
In interpreting this provision and in commencing its reasoning, the court said:

A quick and over-literal reading of $\S 15$ might generate the notion that a hearing is required only if the Commission disapproves an agreement and not if the Commission merely grants approval .... What the words of $\S 15$ fairly indicate is that an appropriate hearing shall be held prior to either approval or disapproval. ${ }^{32}$

The importance of Commission approval of section 15 agreements is stated in the Shipping Act as follows:

Any agreement and any modification or cancellation of any agreement not approved, or disapproved, by the Commission shall be unlawful, and agreements, modifications, and cancellations shall be lawful only when and as long as approved by the Commission; before approval or after disapproval it shall be unlawful to carry out in whole or in part, directly or indirectly, any such agreement, modification, or cancellation. . . .

Every agreement, modification, or cancellation lawful under this section, or permitted under section $813 \mathrm{a}$ of this title, shall be excepted from the provisions of sections 1-11 and 15 of Title 15, and amendments and acts supplementary thereto.3

Thus, agreements not approved are unlawful and may not be implemented but once approved are immune from the anti-trust laws.

The court's conclusion, however, was not that an evidentiary type hearing is always required-only a "hearing." The type of hearing required, the court indicated, may depend upon the issues involved in the particular case..$^{34}$ Nevertheless, it appears from all the surrounding circumstances that the court's interpretation of the hearing requirement is at least unnecessary and certainly open to question. First, it should be noted that the court, after stating the pre-approval hearing requirement, allowed for certain exceptions. According to the court a hearing is not required: (1) "when the Commission has made appropriate determination that certain agreements are of purely routine nature or (2) have an impact on commerce that the Commission finds is de minimis", 3 (3) "if no

32. 420 F.2d at 583-84 (emphasis added); cf. City of Los Angeles v. FMC, 388 F.2d 582, 583 (D.C. Cir. 1967).

33. 46 U.S.C. $\$ 814$ (1964) (emphasis added). The sections of 15 U.S.C. referred to include Sherman Anti-Trust Act, 15 U.S.C. $\$ \S 1-7$ (1964); Wilson Tariff Act, 15 U.S.C. $\S \S 8-11$ (1964): Clayton Act \& 4, 15 U.S.C. § 15 (1964).

34. 420 F. $2 \mathrm{~d}$ at 585 n. $22,586,589-90 \&$ n. 36 .

35. Id. at 584. 
protest is filed;" "3s (4) if there are no issues of "substance" or "obvious gravity";37 or (5) when "an applicant for approval of a restrictive agreement. [satisfies] the burden of demonstrating the need for anticompetitive restraints ....'33 In the presence of such excepted situations, however, exception number three seems to be overriding. If a protest is filed it appears that the court would apply its general rule requiring a hearing unless "no substantial issues are raised' '3s by the protest.

The first two of these exceptions-routine and de minimis agreements-were designated "implied exceptions" but the court's discussion of this point seems somewhat.uncertain. The so-called "exceptions" can and do exist with or without the general hearing rule stated by the court.

Exceptions one and two are applicable, the court indicated, only when they have been created at a previous time for general application. Thus, the court said:

There may be an implied exception to the literal command of Section 15 when the Commission has made appropriate determination . . . .

However, the matter before us is not appropriate for establishing any implied exception to section 15. To begin with, there is no Commission rule announcing an exemption for the agreements involved."

For this statement the court cited section 35 of the Shipping Act-added to the Act in 1966-which provides that the Commission "may by order or rule exempt for the future any class of agreements ... from any requirement of the Shipping Act, 1916 ... where it finds that such exemption will not substantially impair effective regulation . . . be unjustly discriminatory, or be detrimental to commerce."

From the court's discussion of routine and de minimis agreements (implied exceptions) and of section 35 agreements (exemptions) together, it appears the court included the former in the latter. Since, however, the Congress has enacted a special section permitting exemptions which would include routine and de minimis

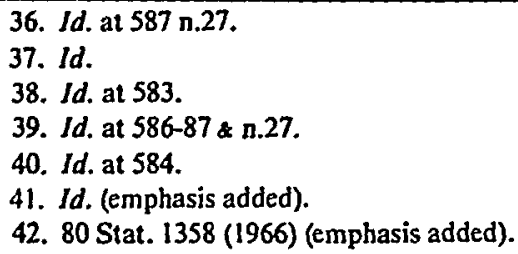


agreements, there is no need for establishing a separate category of "implied exceptions" as did the court. This confusion is avoided, however, by concluding that the exceptions and exemptions are two. separate categories of agreements, a conclusion compelled by several factors.

In the first place, agreements which are exempted under section 35 do not receive antitrust immunity. Only agrcements which are approved can obtain immunity, and the Commission, in the most recent case in which an agreement exemption has been granted, specifically denied a request by a party for a Commission statement to the effect that exempted agreements are immune..$^{43}$ Exceptions are entirely different. The court seems to have used the term to mean agreements for which no hearing must be held prior to their approval. Agreements exempted from the filing for approval requirements of the Shipping Act are relieved of the need to get approval to begin with, and such agreements, therefore, are not subject to the prohibition against implementing unapproved agrcements and the attendant penalty provision." Consequently, the category of exempted agreements should not enter into a discussion of section 15 approval. Furthermore, there is an internal Commission system of "delegation" for the expeditious approval of agreements of the type the court called "implied exceptions." Under this system the Commission has delegated to members of its staff the authority to approve certain unprotested agreements and modifications or cancellations thereof. ${ }^{45}$

An interesting point here is that the "exeeptions" almost equal the "rule." Between March 1 and November 30, 1969, the Commission approved 167 agreements or modifications subject to section 15. Of these, 87 (52 percent) were approved under delegated

43. FMC General Order 23 (May 13, 1968), 46 C.F.R. \$\$ 524.1..6 (1969). In the only other such exemption created to date the Commission stated that no immunity attaches to exempted agreements. FMC General Order 4, amend. 11 (April 21, 1967), 46 C.F.R. \& $510.26(b)(1969)$.

44. See note 33 supra and accompanying text. Anyone violating $\S 15$ is subject to a penalty of up to $\$ 1,000$ a day, 46 U.S.C. $\S 814$ (1964).

45. The basis for the establishment of this system of delegation is in Reorganization Plan No. 7 of 1961 whereby the Federal Maritime Commission was established as an independent regulatory agency-an arm of the Congress. 5 U.S.C. $\$ 133 z-15$ note (1964). Reorganization Plan No. 7, $\S 105$, authorizes the Commission to delegate any of its functions; and this authority has been exercised in Commission Order 1 (Revised) and Amendments 3 \& 4 (denoted in Federal Register as Amendments 2 \& 3), 34 Fed. Reg. 2278 (1969); 33 Fed. Reg. 11863 (1968); 31 Fed. Reg. 15110 (1966). 
authority, and 12 (7.2 percent) were subjected to a hearing. Of the agreements approved by delegation, none was later reviewed by the Commission and set down for a hearing.

Thus, by congressional permission, the FMC is empowered to exempt entirely some agreements from the approval requirements and to approve other agreements by delegation in a manner which precludes the holding of a hearing. ${ }^{40}$ Consequently, less than a majority of agreements-80, or 48 percent of those approved-may exhibit a prima facie need for a hearing; that is, are not permitted to be approved under delegated authority. Then again these agreements are also amenable to exceptions according to the court, but not the implied exceptions. When these other exceptionsnumbers 3, 4 and 5, supra-are applied to the March-November. 1969 period, records of the FMC reveal that only 15 percent of the 80 agreements not covered by delegation-by the implied excep. tions-were actually set down for a hearing. 47

It appears, therefore, that the requirement stated by the court that all section 15 agreements be set down for hearing prior to approval is really the exception to the rule of experience. As a result, what emerges is an outline of Commission procedure consistent with that set forth by the court. The significant difference is the starting point for the procedures. Whereas the court proceeded from the requirement of a pre-approval hearing which can be avoided only when certain exceptions apply, the Commission has acted under the assumption that no hearing is required, and that wherever possible agreements should be processed for approval without a hearing. In this connection the court made a pertinent comment. The court found it "hard to believe" that a hearing is required for disapproval of an agreement, but that the Commission could confer approval "on the basis of back-office and one-sided conversations, and unpublished disposition unaccompanied by reasoned analysis and opportunity for appropriate presentation of objection, evidence and argument."48 This statement could be given more than one

46. It should be noted, however, that parties to a type of agreement for which an exemption has been granted can still obtain approval of such agreement, 46 C.F.R. 524.6 (1969), and, also, approvals granted under delegated authority are subject to review by the Commission. Reorganization Plan No. 7 of 196I, § 105(b), 5 U.S.C. § 133z-15 note (1964).

47. These figures are from the files of the Federal Maritime Commission. The March 1November 30, 1969 period is the only recent period for which complete statistics on this subject are available at the time of this writing.

48. 420 F.2d at 584 . 
interpretation. It could mean that improper ex parte activity must not be engaged in so as to deprive a protestant raising substantial issues of his right to have them properly and fairly aired and. considered. With this there can be no disagreement. However, the court's comment seems rather to be used as an argument in support of the conclusion that pre-approval hearings are required. In this respect the argument is not realistic when viewed in light of Commission experience.

Of the 167 agreements approved by the Commission in the March-November period, 155 were approved without a hearing. Commission experience with such approvals reveals that only in very rare instances is approval granted to agreements in the form in which they are first submitted. Generally there is some give and take between agreement proponents, protestants, if any, and the Commission. Even in the absence of protests the Commission is rarely satisfied with agreements as submitted and usually requests the parties to make modifications. ${ }^{49}$ The parties are often advised that failure to make the requested modifications will result in the Commission ordering the proposed agreement set down for a hearing.

When protests, or comments, are filed pursuant to Federal Register notice, the Commission gives proponents an opportunity to respond to them, and an attempt is made to satisfy the protestants to the extent their points are meritorious. In the great majority of instances protestants are ultimately satisfied and their protests withdrawn. It sometimes happens, however, that protestants are either unsatisfied or unwilling to withdraw their protests, but the Commission nevertheless grants approval without a hearing. When such action is taken, the Commission order of approval summarizes the protests and gives reasons for not accepting them. There is not recallable an instance-at least prior to Marine Space Enclosures-in which a protestant has sought reconsideration or review of any such approval through available means..$^{\mathbf{3 0}}$

Despite the fact that this modus operandi may sometimes involve "back-office and one-sided conversations," failure to afford due process. In fact, the Commission's procedure

49. Certain items are required to be included in agreements. 46 U.S.C. $\$ 814$ (1964).

50. Possible avenues to review are Shipping Act, 1916, § 22, 46 U.S.C. $\S 821$ (1964), and 28 U.S.C. $\S \S 2342-43$ (Supp. IV, 1969).

51. 420 F.2d at 584. 

delay. ${ }^{54}$ Such action is supported by the recent case of Sea-Land Service, Inc. $v$. Conner, ${ }^{55}$ cited by the court in Marine Space Enclosures: "[I]n an appropriate case, the [Maritime Subsidy] Board may dispense with a hearing and support its procedural course, by virtue of meaningful findings, based on its expertise in appraising materials in its open files . . . ."

This is not to say, however, that it would be permissible in all cases for the Commission to approve, without a hearing, agreements which are unprotested and with respect to which the Commission has satisfied itself as to prima facie approvability through contacts with proponents. There are times when an airing of issues through briefs or other submissions will be helpful in demonstrating a need for particularly anticompetitive restraints, ${ }^{57}$ and the FMC has a Bureau of Hearing Counsel through which the public interest is actively represented by attorneys in cases before the Commission. Furthermore, there are some cases in which due process requires a hearing regardless of statutory provisions..$^{58}$

It is not here contended that the Commission must act only in response to protests: "In discharging our duties under section 15, we are not limited to those matters parties to agreements wish us to see. We are required to go further . . . . To decide otherwise [would be] at the expense of our regulatory responsibility." has a statutory obligation to guard the public interest independent of the interests of private parties. ${ }^{80}$

The intent of Congress is better sought by examining the legislative history of section 15 , and the first thing to be noted is that a hearing requirement was not provided for in that section in the original Shipping Act of 1916.81 Not until 1961 did Congress amend

\footnotetext{
54. See notes 49-50 supra and accompanying text.

55. 418 F.2d 1142 (D.C. Cir. 1969).

56. Id. at 1149.

57. See, e.g., FMC v. Svenska Amerika Linien, 390 U.S. 238 (1968).

58. See, e.g., L.B. Wilson, Inc. v. FCC, 170 F.2d 793 (D.C. Cir. 1948).

59. Agreement No. T-4: Terminal Lease Agreement at Long Beach, California, 8 F.M.C. 521,529 (1965).

60. See Investigation of Passenger Steamship Conferences Regarding Travel Agents, 10 F.M.C. 27 (1966). "Section 15's authorization of agreements . . . does not dictate approval simply because such an agreement is filed and approval is desired by the parties to the agreement." Id. at 34 . For the writer's previously stated views concurring on this point, see his separate opinion in Merger-American Mail Line, American President Lines, Pacific Far East Line, II F.M.C. 53, 72 (1967). See also Michigan Consol. Gas Co. v. FPC, 383 F.2d 204 (D.C. Cir.), cert. denied, 364 U.S. 913 (1960).
}

61. Ch. 451,39 Stat. 733. 
the Act to provide for a hearing. ${ }^{.2}$ However, Congress made several amendments to the Shipping Act at that time, the most notable being that which permitted exclusive patronage-dual rate-contracts in our foreign waterborne commerce, ${ }^{63}$ and, consequently, the bulk of the legislative history deals with that amendment and not too much is to be gleaned as to hearing requirements. Nevertheless, there are indications as to what was intended by the 1961 changes in section 15 .

Section 15 originally read, in pertinent part: "The board may by order disapprove ... and shall approve all other agreements, modifications, or cancellations."64 The amendment process began with the introduction in the House of Representatives of H.R. 4299 on February 15, 1961, which provided: "The Board shall by order after notice and hearing disapprove . . . and shall approve all other agreements, modifications, or cancellations that it affirmatively finds to be in the public interest."'ss Thereafter, extensive congressional hearings were conducted, during various stages of which modifications were made in the proposed amendment to section 15. No apparent objections were made to the amendment providing for notice and hearing before disapproval. There were, however, comments directed against the requirement that approval be based upon an affirmative finding that an agreement is in the public interest.

One witness ${ }^{66}$ before a special subcommittee of the House of Representatives Committee on Merchant Marine and Fisheries was disturbed by some of the language of H.R. 4299. He contended that, if left unchanged, the bill would add to the Shipping Act the requirement that the Commission "give notice and hold a hearing on every agreement .... . . . [ [would require] the ... [Commission] to disapprove any agreement which it does not affirmatively find in the public interest." ${ }^{\circ 7}$ The witness foresaw this

62. 46 U.S.C. $\$ 814$ (1964).

63. Shipping Act, 1916, § 14b, 46 U.S.C. § 813a (1964).

64. Ch. 451,39 Stat. 734 (emphasis added).

65. H.R. 4299, 87th Cong., Ist Sess. (1961); see Hearings on H.R. 4299 Before the Special Subcomm. on Steamship Conferences of the House Comm. on Merchant Marine and Fisheries, 87th Cong., Ist Sess. (1961) (emphasis added) [hereinafter cited as House Hearings].

66. Donald F. Wierda, vice president of freight traffic of the United States Lines Co., appeared on behalf of the American Steamship Committee on Conference studies. House Hearings 60.

67. Id. at 74 . 
result in the requirement in the bill that the Commission make an affirmative finding regarding the public interest prior to approval. To avoid such a pervasive pre-approval hearing requirement and to permit Commission approval without a hearing, the witness recommended that the affirmative hearing requirement be deleted from the bill..$^{68}$

Similarly-focused comments were made by Thomas E. Stakem, then Chairman of the Federal Maritime Board, ${ }^{69}$ and the Department of Commerce-which then housed the Federal Maritime Board. In suggesting the deletion of the "affirmative finding" requirement, Mr. Stakem said: "It is believed that all agreements which satisfy those standards [which call for disapproval if offended] should be approvable . . . without the need for a further affirmative finding that the agreement is in furtherance of the public interest." The Department of Commerce commented as follows after recommending the same deletion:

In conformity with other similar statutes . . . we believe that if a public interest standard is to be applied ... it should be phrased in terms of permitting the approval of agreements ... not [found] to be adverse to the public interest ... . Requiring a positive finding . . . would prevent carriers from operating under arrangements which, although not meriting disapproval . . could not be shown to positively contribute to the public interest."

After these comments were received there appeared on March 23, 1961, a Committee Print of a revised form of H.R. 4299.72 That version of the bill deleted the "affirmative finding" requirement and reverted to the language of the original Act: "and shall approve all other agreements, modifications, or cancellations." 73 This was quickly undone, however, when draft revision No. 2 was published by the subcommittee on April 13. That version read: "The Board shall by order after notice and hearing disapprove ... and shall

68. Id. at 67.

69. The Federal Maritime Board was the predecessor of the Federal Maritime Commission. Reorganization Plan No. 21 of 1950, 5 U.S.C. § 133z-15 note (1964).

70. House Hearings 25.

71. Id. at 7.

72. Staff of the Special Subcomm. on Steamship Conferences of the House Comm. on Merchant Marine and Fisheries, 87th Cong., Ist Sess., H.R. 4299, Draft Reviston No. 1 (Comm. Print 1961); see Office of General Counsel, Federal Maritime Commission, Steamship Conference Dual Rate Law (P.L. 87-346), Legislative History (undated) (available in FMC Library).

73. 46 U.S.C. § 814 (1964). 
approve all other agreements, modifications, or cancellations that it finds not contrary to the public interest." $"$ 4

During the intervening period a witness testified as being in favor of retaining the need for an "affirmative finding": "The bill rightly says, in effect, that the anti-trust laws shall not be set aside in the absence of a definite need; if the Board cannot find such a need in the given case it plainly ought not to grant the exemption."75

Oddly, however, another comment of the same witness supported a suggestion of the Department of Commerce, ${ }^{76}$ which would have eliminated the pre-approval hearing requirement. It was suggested that the words "notice and hearing"-prior to disapproval-be replaced by "publication and notice in the Federal Register and affording to all interested parties an opportunity for hearing." change, the Department of Commerce said, was to avoid a construction of the bill which would "require a hearing in connection with every agreement without regard to whether any person having a bona fide interest requests a hearing." 78

Hearings were continued after publication of the April $13 \mathrm{draft}$ No. 2 and opposition continued to the "affirmative finding" provision: "This requirement for an affirmative finding would seem to mean that there could be no approval without some sort of hearing to provide facts upon which this ultimate and vague finding could be predicated." 79

On May 2, 1961, the subcommittee reported H.R. 4299, which was introduced the next day as "clean bill" H.R. 6775; on May 4 . the full House committee ordered H.R. 6775 reported; on June 12 the bill passed the House-all without further pertinent amendment of the April 13 draft. ${ }^{80}$

The Merchant Marine and Fisheries Subcommittee of the Senate Committee on Commerce commenced hearings on the subject on

74. Staff of the Special Subcomm. on Steamship Conferences of the House Comm. on Merchant Marine and Fisheries, 87th Cong., Ist Sess., H.R. 4299, Draft Revision No. 2 (1961) (emphasis added); see Merchant Marine and Fisheries Subcomm. Of the Senate Comm. on Commerce, Index to the Legislative History of the Steamship Conference/Dual Rate Law, S. Doc. No. 100, 87th Cong., $2 d$ Sess. 28 (1962) thereinafter cited as DUAL RATE LAW INDEX]; House Hearings 539-40.

75. House Hearings 418.

76. Id.

77. Id. at 7.

78. Id.

79. Id. at 510 .

80. Dual Rate Law Index 28. 
June 16. On August 8 the subcommittee released its version of the bill, which departed from the House-passed bill by deleting all reference to an affirmative finding prior to approval of an agreement. ${ }^{81}$ During the Senate hearings the most relevant comment relating to that part of the bill concluded:

This short phrase ["that it finds not contrary to the public interest"] means that the Board would be required to have a hearing on every agreement filed with it for approval under section 15 since the term "finds" legally imports a public hearing.

This . . . requirement . . . would immesh the Federal Maritime Board and parties subject to the act in interminable litigation that would make all of section 15 unworkable. ${ }^{82}$

The bill as printed by the subcommittee on August 8 proceeded without pertinent change when reported by the Senate Committee on August 31 and passed by the Senate on September $12 . .^{33}$ Congress, on taking final action, accepted the Senate version.

It seems significant that all attempts to amend section 15 to require specific findings prior to approval-as required before disapproval-met with failure. The argument might be made, however, that Commission and court cases which place the burden on proponents of agreements to "demonstrate that the agreement is required by a serious transportation need"'B4 have negated any possible significance of the failure to enact those amendments. ${ }^{85}$ This position is, however, questionable. Although a burden has been shifted to the proponents of an agreement, the proponent of an order-in this case an order of approval-usually has the burden of proof. ${ }^{88}$ All that is shifted is the burden of going forward with the evidence. Thus, in cases where proponents of an agreement are required to justify its need, there is already a prima facie case against

81. Staff of the Subcomm. on Merchant Marine and Fisheries of the Senate Comm. on Commerce, 87th Cong., ISt Sess. H.R. 6775 (Subcomm. Print 1961); see îtearings on H.R. 6775 Before the Subcomm. on Merchant Marine and Fisheries of the Senate Comm. on Commerce, 87th Cong., Ist Sess., pt. 2, at 607 (1961) thereinafter cited as Senate Hearings].

82. Senate Hearings 243.

83. Dual Rate Law INDEX 28.

84. Investigation of Passenger Steamship Conferences Regarding Travel Agents, 10 F.M.C. 27, 34-35 (1966); see, e.g., FMC v. Svenska Amerika Linien, 390 U.S. 238 (1968); Mediterranean Pools Investigation, 9 F.M.C. 264 (1966).

85. See Brief for Petitioners, Marine Space Enclosures, Inc. v. FMC, 420 F.2d 577 (D.C. Cir. 1969).

86. Federal Maritime Commission, Rules of Practice and Procedure, Rule 10(0), 46 C.F.R. § 502.155 (1969). 
approval which the proponents must overcome. This holds whether the prima facie case is established by the Commission's investigation of the agreement on its own motion or by a protestant. Inasmuch as an agreement cannot be disapproved without a hearing, a hearing is always required in cases where there is a prima facie case warranting disapproval.

Consequently, when the Commission institutes a hearing to determine whether a proposed agreement should be approved or disapproved, it is for the purpose of giving the agreement's proponents an opportunity to overcome the prima facie case for disapproval. Before the hearing is concluded it cannot be known whether the proponents will be able to meet their burden, and, therefore, the hearing must be held in order for the Commission to be permitted to disapprove the agreement if the prima facie case for disapproval is not overcome. The argument is, therefore, not supported that a shifting of the "burden" to agreement proponents is evidence of a pre-approval hearing requirement.

Thus, the court's conclusion that hearings are always required prior to approval appears entirely unneeessary because in a prima facie case requiring disapproval, a hearing is required by the terms of section 15; if there is no such case, the legislative history, as we have thus far discussed, fairly indicates that there was no congressional intent to require a hearing before every approval. Furthermore, there is no additional evidence, either in the legislative history or elsewhere, to lead one to a different conclusion. The little remaining evidence, ${ }^{87}$ is somewhat tangential but tends to add support to the conclusion that there is no mandated pre-approval hearing requirement.

First, there is Isbrandtsen Co. v. United States, ${ }^{88}$ a case cited in the legislative history ${ }^{80}$ and by other forums ${ }^{90}$ for the proposition, inter alia, that the Commission must hold a hearing prior to approving agreements under section 15 . Nevertheless, the language of the decision in Isbrandtsen demonstrates that the court did not so hold." There the Commission's predecessor agency had before it a steamship conference agreement to institute an exclusive

87. See notes 88-101 infra and accompanying text.

88. 211 F.2d 51 (D.C. Cir.), cert. denied. 347 U.S. 990 (1954).

89. See, e.g., S. ReP. No. 860,87 th Cong., Ist Sess. 8-9 (1961); 107 Cong. ReC. 19410 (1961).

90. FMB v. Isbrandtsen Co., 356 U.S. 481,486 \& n.7 (1958).

91. The Isbrandtsen case was not cited by the court in Marine Space Enclosures. 
patronage-or dual rate-contract system..$^{92}$ The agency ordered a hearing on the contract but permitted it to go into effect immediately. The complainant filed its petition in the court of appeals to review the Board's having permitted it to become effective prior to a hearing. The court set aside the Board's action, but the plain meaning of the court's language indicates only that the Board had not approved the system as required by section 15 . This is revealed in the following excerpts from the court's opinion:

Clearly, a scheme of dual rates like that involved here is an "agreement" .... It can hardly be classified an interstitial sort of adjustment . . . . But even if it were not a new agreement, it would certainly be classed as a "modification" of the existing basic agreement. In either case, $\S 15$ rcquires that such agreements or modifications "shall be lawful only when and as long as approved" by the Board." Until such approval is obtained, the Shipping Act makes it illegal to institute the dual rate system.3

2s We understand the Board to agree that if the dual rate agreement here requires Board approval under $\S 15$, the agreement could not be validated by the General Order 76 proeedure prior to such approval. . . .

We hold that the action of the Board in allowing the dual rate system agreement to go into effect prior to approval . . . is contrary to the specific requirement of $\S 15$ of the Shipping Act making Board approval a necessary condition precedent to initiation of such an agreement."

This language cannot fairly be read to mean that the cqurt interpreted section 15 to require a pre-approval hearing. Consequently, reliance on the case in the legislative history for that proposition is misplaced. Even so, the case was relied upon, and it is worth examining at least one example of that apparent misreliance. Whether or not the interpretation of 1 sbrandtsen was accurate, the meaning placed on the case may reveal something of the congressional intent.

The most pertinent citation of 1sbrandisen appears not in any discussion of section 15 but, strangely, in a discussion of the provision in H.R. 6775 which authorized the type of exclusive patronage contracts at issue in Isbrandtsen. It is important to note that 1 sbrandtsen dealt only with section 15 ; there was no provision then in the Shipping Act dealing with exclusive patronage contracts.

92. $211 \mathrm{~F} .2 \mathrm{~d}$ at 53.

93. Id. at 56. See the exception to the approval requirement in the fourth paragraph of section 15, 46 U.S.C. $\S 814$ (1964).

94. 211 F.2d at 57 (emphasis added). 
References were made to the case in the legislative history only for the purpose of buttressing arguments for adoption of the exclusive patronage provision of the proposed legislation. ${ }^{95}$

During the Senate floor debate on the exclusive patronage provision of H.R. 6775, now section 14b of the Shipping Act, Senator Kefauver invoked the Isbrandtsen case in support of his proposed amendment to that provision but not in regard to any aspect of section $15 . .^{77}$ In view of the fact that Senator Kefauver was evidently concerned only with section $14 \mathrm{~b}$ and that Isbrandtsen was being misinterpreted as to section 15 , it cannot be said that there was an intent in Congress to tamper with what appears to have been the then determined amended meaning of section 15-that a hearing is required prior to disapproval but not approval. This is illustrated by Senator Kefauver's comments in support of the amendment. ${ }^{98}$

The language of H.R. 6775 and Senator Kefauver's amendment was: "[T]he [Federal Maritime] Board . . . shall, after notice, [and hearing] permit the use . . . of any contract . . . ."998

In support of this amendment, the Senator said:

Mr. President, everywhere else in the bill it is provided that where some action is to be taken by the Maritime Commission, both notification and hearing shall be given ....

As the bill is presented, it provides that after the notice, the Commission may agree to a conference [read: may approve an exclusive patronage contract]. It does not say anything about giving anyone a hearing in connection with the questions involved. The amendment would simply insert hearing after the word notice. . . . 100

The Senator's comments on the need to provide a hearing if notice is given, together with the circumstances surrounding the failure to amend the approval aspect of section 15, lead to the conclusion that he was merely conforming language. In other words, Senator Kefauver was referring to the notice and hearing in section 15 only insofar as it was applicable-to. disapprovals. Although this bit of Senate debate is not firm evidence upon which to base a conclusion that there is no mandated pre-approval hearing, neither does it

95. See S. Rep. No. 860, 87th Cong., Ist Sess. $8-9$ (1961).

96. 46 U.S.C. § 813a (1964).

97. 107 CONG. REC. 19410 (1961). The Congressional Record erroneously designated the amendment as "6-1-61-0" instead of "9-1-61-0."

98. Id.

99. Senate Hearings pt. 1, at 2.

100. 107 CONG. REC. 19410 (1961) (emphasis added). 
appear to offer much support for the conclusion drawn by the court in Marine Space Enclosures that such a hearing is required by the language of section $15 . .^{101}$

\section{IV}

The legislative history of the 1961 amendments to section 15, in addition to court precedents, does not seem to support the court's conclusion in Marine Space Enclosures that a pre-approval hearing is required by congressional mandate. In fact, it appears to prove the contrary. Nevertheless, the legislative history is admittedly somewhat unclear and confusing and could be considered inconclusive.

The legislative history aside, however, it cannot be determined, as a practical matter, that the court's conclusion is necessary. With or without that conclusion the court and past Commission practice reach much the same result. If it is assumed that no pre-approval hearing is required, the Commission is, in every case, left with the decision when to hold a hearing to meet the requirements of due process. The Commission then would have the discretion to make that decision, and an aggrieved party could seek redress in the courts which might find an abuse of discretion in the Commission's failure to hold a hearing. ${ }^{102}$

If a pre-approval hearing is required, discretion is again left with the Commission in every case. The Commission would determine when to apply an exception to the hearing requirement, and again, a court might then find an abuse of this exercise of discretion. In either case it is the Commission which makes the initial determination as to when a hearing is required, and it must be assumed that the Commission will-as will any such body-act within the law and abide by established precedent. With regard to the FMC, from the statistics cited earlier and the history of the Commission, at least since 1961, it can be fairly said that the Commission has not exhibited any laxness in this area. The Commission has acted under the assumption that matters of a significantly restrictive nature and agreements apparently in substantial violation of the anti-trust laws require the type of hearing appropriate under the circumstances. ${ }^{103}$

101. 420 F.2d at 584.

102. Cf. 5 U.S.C. § 706 (Supp. IV, 1969).

103. See, e.g., Inter-American Freight Conference Agreements, I1 F.M.C. 332 (1967); 
In addition, the Commission has a well developed internal system for processing proposed agreements which comports with that outlined by the court. The court's system of exceptions is one with which the Commission is already prepared to deal in a manner consistent with statutory provisions and with the court's own guidelines. The FMC is a quasi-judicial body established by Congress primarily for protecting the public interest in our country's foreign waterborne commerce. ${ }^{104}$ The Commission therefore, must always act in the public interest, whether that be through holding hearings to analyze weighty issues or through expeditious treatment of agreements to permit the commencement or improvement of shipping services. To accomplish these ends the Commission cannot be tied down by needless formalities, but must make the statutes under its jurisdiction workable through the judicious use of flexible alternatives. ${ }^{105}$

Thus, while it is difficult to disagree with the court's decision to remand the Marine Space Enclosures case, it is equally difficult to agree with the route the court chose to reach its ultimate conclusion. Furthermore, there are indications in the court's opinion that regardless of the hearing requirements of section 15 , the court actually reached its decision primarily because the Commission failed adequately to support its decision:"108 "The discussion [in the Commission's Order of Approval] is couched in conclusory terms without any support of record. . . . These recitations [by the Commission] are ample in rhetoric, but 'sparing in detail.' They are without support in the record . . . ."107 It thus appears entirely unnecessary for the court to have premised its decision on a preapproval hearing requirement.

Although the previous discussion is critical of the court's conclusion that a pre-approval hearing is always required, there is

\footnotetext{
Merger-American Mail Line, American President Lines, Pacific Far East Line, 11 F.M.C. 53 (1967); Stock Purchase Agrcement Between Prudential Lines and W.R. Grace \& Co., FMC Docket No. 69-51 (Dec. 22, 1969); Agreement No. 9827 Between United States Lines and Sea-Land Service, Order for Investigation and Hearing, FMC Docket No. $69-56$ (Nov. 25, 1969). See also Marine Space Enclosures, Inc. v. FMC, 420 F.2d 577 (D.C. Cir. 1969).

104. See Reorganization Plan No. 7 of 1961, § 103, 5 U.S.C. \& 133z-15 note (1964).

105. See California v. United States, 320 U.S. 577, 584 (1943).

106. Cf., e.g., United States Atl. \& Gulf/Australia-New Zealand Conference v. FMC, 364 F.2d 696, 699 (D.C. Cir. 1966).

107. 420 F.2d at 587-88.
} 
an aspect of the decision which offers a very important aid to the Commission, that is, the type of hearing to be held in cases which so requirc. The court said that while section 15 requires a preapproval hearing, such hearing shall be an "appropriate" one; ${ }^{108}$ the court refrained from directing the Commission to hold an "evidentiary" hearing. ${ }^{109}$ Thus, what emerges from the court's discussion of this point ${ }^{110}$ is specific recognition of the need for the FMC to tailor, in its discretion, the type of hearing which might be required in a particular case."11

The requirement of a hearing . . . may be satisfied by something less timeconsuming than courtroom drama. ${ }^{112}$

The requirement of an evidentiary hearing is not a mandate of a prolix procedure protracted beyond . . . the requirements of the issues. ${ }^{.13}$

While these hearing guidelines have general applicability in administrative proceedings, ${ }^{114}$ it is particularly desirable and most helpful to have such a clear statement of the permissible flexibility of hearings which may be ordered by the Federal Maritime Commission. The need for a hearing and the type of hearing to be conducted are issues that have been problematical to the Federal Maritime Commission for quite some time. Hopefully, the above treatment of the questions will, in addition to exposing the issues to some examination, be of help to those who must deal with the merits of the issues on a practical day to day basis.

108. Id. at 584 .

109. Id. at 590 .

110. Id. at $589-90$.

111. Id. at 589 n.36; American Airlines v. CAB, 359 F.2d 624, 631 (D.C. Cir.), cert. denied, 385 U.S. 843 (1966).

112. 420 F.2d at 589.

113. Id. at 590.

114. Id. at 589. 